\title{
Assertive Communication Training to The Wives of Fisherman As A Social Support to Reduce Father Smoking Intensity in The House
}

\author{
Nurul Haniza \\ Universitas Sahid Jakarta, DKI Jakarta 12870, Indonesia \\ Author E-mail: hanizanurul6@gmail.com
}

\section{A B S T R A C T}

Children who are exposed to secondhand smoke from their parents are more at risk of suffering from vascular and heart health problems in the future. In addition, smoking behavior in fathers also causes low nutritional status in the smokers' families. Stopping smoking is very difficult, so smoking away from children is one solution that can be offered to keep children from being exposed to cigarette smoke but fathers can still smoke through a process of communication between partners. The purpose of the study is to determine the effectiveness of assertive communication training to the wives as a form of social support for the father's smoking behavior (to smoke outside the home). The intervention was conducted in the form of assertive communication training on wives. The location of the training was conducted in the Fisherman Village in Bulukumba District, South Sulawesi. The topic is "Communication in an assertive way" is considered important to do so that the father does not feel disturbed from the "pleasure" of smoking. The participants are 26 wives of the fishermen. The wife was chosen to be the target of the intervention because the female partners would easily influence her male partners in changing his negative behavior. All statistical tests on the pre-test and post-test assertive communication training, and pre-test and post-test intense fathers smoking outside the home were conducted with non-parametric test methods taking into account the number of samples $n=<30$, and the significance assumption of $5 \%$. The results of the study conducted showed that assertive communication given to fishermen's wives had not provided the ability for mothers to assert communication with their fathers to reduce smoking at home. $((\mathrm{Mdn}=24.50)$ in the pre-test and $(\mathrm{Mdn}=23.50)$ in the post-test, in the post-test, $\mathrm{z}=-0.446, \mathrm{p}<0.5 ; \mathrm{r}=$ -0.152). This is because the language of the material uses the language of "science" which is not understood because of the low education of the fishermen and the fairly short intervention time. The conclusion of the study showed that there was no changes in assertive communication skills in the intervention subjects (mothers) after being given treatment or assertive communication training interventions. In terms of knowledge, the intervention subject gets a better understanding, but the skills or skills to make communication are still inadequate. Nevertheless, the social control function of the family in terms of changing smoking behavior must be fixed and continuously improved by providing the awareness of health hazardous due to smoking behaviors. Suggestion: Assertive communication training needs to be followed up by health workers to limit the smoking behavior of fathers inside the house, and it needs to be supported by the media coverage on health communication.

Key word: Assertive Communication Training, Behavior Management, Social Support, Smoking Behavior. 
Copyright (C) 2021 Authors. This is an open access article distributed under the Creative Commons Attribution License, which permits unrestricted use, distribution, and reproduction in any medium, provided the original work is properly cited.

\section{INTRODUCTION}

Indonesia is the country with the largest number of smokers in the world. Based on the results of the study on 33,000 Javanese families in Indonesia, it is said that smokers in rural Indonesia finance their habits by taking family funds which ultimately causes malnutrition in their children. The average family where one of its members smokes, uses $10 \%$ of the budget for cigarettes, then $68 \%$ of the family budget is for food, and $22 \%$ for non-food, non-smoking purchases. While for non-smoking families, they spend $75 \%$ of their income on food and $25 \%$ on non-food items.

Although anti-smoking campaigns have been conducted and the negative impact of smoking has also been recognized by many people including smokers themselves, but generally smokers have a low need to quit smoking (Yun, Kang, Lim, Oh \& Son, 2010). Based on the data, specifically in Indonesia, cigarettes are a necessity for smokers. Stopping smoking is difficult, then smoking outside the home is one solution that can be offered so that children are not exposed to the cigarette and the smoke.

To be able to change smoking habits, various supports also need to be considered. It can be in the form of support from other parties or social support. Social support aimed at changing this smoking habit is from the wife (Westmaas, Ferrence, \& Willd, 2002; Lichtenstein, Andrews, Barleyley, Akers, \& Severson, 2002). Thus the role of the wife (mother) as a change agent for father's change of behavior is a considerable support. Cigarette researchers also suggest that increasing social support from partners, friends, and colleagues will make it easier for the smokers to quit.

In terms of the role of women in the fishermen's family, at a glance, it is seen that the role of the husband is greater than the wife in the fishing community. But based on the results of a study conducted by Astutie (2008), it turns out that coastal women also have a very important role in the family of fishermen. The characteristics of fishermen who spend more time at sea has made many decision-making roles were carried out by the wives. Although the wives continue to consult with their husbands, their wives also continue to make decisions. Thus the mother (wife) has a very important role in the family not only related to the health problems, but also an important role in the family economy.

Blackburn said that to prevent children from being exposed to cigarette smoke from a new father, changing the behavior of fathers to not smoke inside the house is easier to do than stopping smoking itself. In the design of this service, activity is focused on the wife's efforts not to allow the husband (father) to smoke in the house, especially near children.

Based on the background, the main purpose of this study was to reduce the father's smoking intentions in the house through the mother's social support by giving assertive communication skills training to the fishermen's wives.

\section{MATERIALS AND METHODS Location and Design of The Study}

This research was conducted in Fisherman Village in Bulukumba District, South Sulawesi. The type of research used was observational using a cross-sectional study design.

\section{Population and Respondents}

The population is all fishermen in the fishing settlement area of Dusun Bajang, Gunturu Village, Bulukumba Regency, South Sulawesi, 27 respondents were selected by proportional stratified random sampling who met the criteria of smokers and toddlers and were willing to take part in this study by signing informed consent. 


\section{Method of Collecting Data}

Data collection is done using pre-tested and post-tested questionnaires. At this stage, the questionnaire was made concerning the Theory of Planned Behavior (TPB) compiled by Icek Ajzen. Data collected included the father's smoking behavior factors obtained by interviews using questionnaires (questionnaires). For monitoring of the intervention provided is carried out by observing and monitoring twin filing.

\section{Data analysis}

To assess the effect of assertive communication on the husband's smoking behavior, bivariate analysis using the nonparametric test method was used with consideration of the number of samples $\mathrm{n}=<30$. Calculation of analysis using the Wilcoxon signed ranks test with a 95\% confidence level on the assumption of the significance of $5 \%$.

\section{RESULTS AND DISCUSSIONS \\ Results}

Based on the results of the baseline study Table 1 it can be seen that the characteristics of the respondents had showed that most of the $66.7 \%$ (18 people) of the research subjects had low levels of education, namely only elementary school graduates, $55.6 \%$ (15 people) worked as fishermen and $100 \%$ (27 people) of the research subjects were smokers who consumed cigarettes per day (51.9\%) and most 66.7\% (18 people) started smoking from the age of 15 - 20 years.

To better understand the condition of the subject of the study before intervening and to find out the intensity of the father to smoke far from the child, a survey was conducted which later became the basis (pre-test) in conducting this intervention. The pre-test used is referring to the TPB theory, attitude toward behavior (attitude) is expressed through behavioral beliefs and evaluation belief variables. Subjective norms (the role of the closest person) are explored through questions about motivation to comply and normative belief and perceived control (things that encourage or prevent a person from doing or not carrying out a behavior) are explored through questions of behavior control.

Table 1. Characteristics of The Respondents

\begin{tabular}{|c|c|c|}
\hline Characteristics & $\mathbf{n}=\mathbf{2 7}$ & $\%$ \\
\hline \multicolumn{3}{|l|}{ Usia } \\
\hline 23 - 30 Tahun & 11 & 40,7 \\
\hline$>30-40$ Tahun & 10 & 37,0 \\
\hline$>40-50$ Tahun & 4 & 14,8 \\
\hline$>50$ Tahun & 2 & 7,4 \\
\hline \multicolumn{3}{|l|}{ Pendidikan } \\
\hline SD & 18 & 66,7 \\
\hline SMP & 7 & 25,9 \\
\hline SMA & 1 & 3,7 \\
\hline Tidak Sekolah & 1 & 3,7 \\
\hline \multicolumn{3}{|l|}{ Pekerjaan } \\
\hline Nelayan & 15 & 55,6 \\
\hline Pedagang Ikan & 8 & 29,6 \\
\hline Wiraswasta & 3 & 11,1 \\
\hline Lain-lain & 1 & 3,7 \\
\hline \multicolumn{3}{|l|}{ Penghasilan } \\
\hline$<\operatorname{Rp} 30.000,-$ & 7 & 25,9 \\
\hline Rp 30.000 - Rp 50.000 & 13 & 48,1 \\
\hline$>\operatorname{Rp} 50.000$ & 7 & 25,9 \\
\hline \multicolumn{3}{|l|}{ Merokok } \\
\hline $\mathrm{Ya}$ & 27 & 100 \\
\hline Tidak & 0 & 0 \\
\hline \multicolumn{3}{|l|}{ Mulai Merokok Usia } \\
\hline$<15$ Tahun & 6 & 22,2 \\
\hline 15 - 20 Tahun & 18 & 66,7 \\
\hline$>20$ Tahun & 3 & 11,1 \\
\hline \multicolumn{3}{|l|}{ Komsumsi Rokok Perhari } \\
\hline$<1$ Bungkus & 4 & 14,8 \\
\hline 1 Bungkus & 14 & 51,9 \\
\hline$>1$ Bungkus & 9 & 33,3 \\
\hline
\end{tabular}

Sumber: Data Primer, 2017

Table 2. Nilai Sikap Responden, Nilai Mean dan SD

\begin{tabular}{ccccc}
\hline \multirow{2}{*}{$\begin{array}{c}\text { Item Attitude } \\
\text { Toward Behavior }\end{array}$} & \multicolumn{2}{c}{ Behavioral Belief } & \multicolumn{2}{c}{ Evaluation Belief } \\
\cline { 2 - 5 } & Mean & SD & Mean & SD \\
\hline 1 & 2,70 & 0,66 & 2,59 & 0,74 \\
\hline 2 & 2,51 & 0,80 & 2,37 & 0,83 \\
\hline 3 & 2,92 & 0,26 & 2,55 & 0,69 \\
\hline 4 & 2,37 & 0,83 & 2,40 & 0,74 \\
\hline 5 & 2,70 & 0,60 & 2,55 & 0,69 \\
\hline
\end{tabular}

Catatan: $n=27$, Sikap terhadap perilaku 5 item, skala $-3 \mathrm{~s} / \mathrm{d}+3$

Table 2 shows all the mean items of attitudes which consist of behavioral aspects of belief and 
evaluation of belief which are at a positive and high level because it is almost close to the maximum value (scale -3 to +3 ). This shows that respondents have a positive attitude towards behavior to smoke outside the home.

Table 3. The aspect of motivation to comply shows the mean of the desire to follow the significant others (wife and daughter) on items and 2 is lower than the mean in item 3 , which is to follow the wishes of the mother (female parent). Whereas in the normative belief aspect which is the expectation of the significant others towards respondents, the mean in item 1 (wife) is higher or approaching the maximum value $(+3)$ than the mean in items 2 and 3 (girls and parents).

Table 3. Nilai Subjective Norms Responden, Nilai Mean dan SD

\begin{tabular}{ccccc}
\hline \multirow{2}{*}{$\begin{array}{c}\text { Item Attitude } \\
\text { Toward Behavior }\end{array}$} & \multicolumn{2}{c}{ Behavioral Belief } & \multicolumn{2}{c}{ Evaluation Belief } \\
\cline { 2 - 5 } & Mean & SD & Mean & SD \\
\hline 1 & 1,48 & 1,60 & 2,44 & 0,93 \\
\hline 2 & 1,70 & 1,51 & 1,33 & 1,46 \\
\hline 3 & 2,33 & 1,14 & 2,00 & 1,17 \\
\hline
\end{tabular}

Catatan:

$\mathrm{n}=27$, Subjective Norms responden 3 item, skala $-3 \mathrm{~s} / \mathrm{d}+3$

Based on the results of the baseline study above, it can be seen that the aspects related to attitudes, behavioral beliefs, and evaluations related to questions about children's health, smoking, and smoking far from children, it can be concluded that it approaches the maximum value $(+3)$. Thus it can be concluded that respondents have a positive attitude towards children's health and smoking far from the children. In the second aspect related to subjective norms which are depicted in the variable motivation to comply and normative belief, it is found that the majority of the mean values of the respondents are highest for wives. Thus it can be concluded that respondents understand the wife's desire to smoke far from the child.

After doing the baseline activity, then the assertive communication training is carried out for the fisherman's wife. Assertive communication training is carried out for 3 meetings with the total number of7 sessions. The purpose of this training is to provide assertive communication skills to mothers so they can reprimand or remind their father to smoke far from their children and do it outside the home.

Assertive communication training begins with giving a pre-test to assess the ability of fishermen's wives to carry out effective communication, followed by training materials and ending with a post-test to measure the effectiveness and success of the training. The training participants were also given a monitoring form which aimed to monitor whether the assertive communication training provided was carried out by the trainees.

To see the effectiveness of this intervention, a statistical test using the nonparametric test method was carried out with consideration of the number of samples below 30 or $n=27$. The statistical tests performed using the Wilcoxon signed ranks test technique obtained data (Mdn $=24.50)$ at the pre-test and $(\mathrm{Mdn}=23.50)$ in the post-test, in the post-test, $\mathrm{z}=-0.426, \mathrm{p}<0.5 ; \mathrm{r}$ $=-0,152)$. Based on the results of the pre-test and post-test of the assertive communication training intervention when viewed from the median value, there was no increase in changes in assertive communication skills in the mother after being given treatment or assertive communication training intervention on the intention of father's smoking behavior in the house.

\section{Discussion}

Based on the results of the study, it was shown that mothers and also fathers had negative views on smoking and were very concerned about the health of their families. However, smoking behavior regardless of its place is carried out by the husband, even smoking activities are more done in the house. Economically the costs incurred by the family for husband's cigarettes are also relatively large (20\% - 50\%) of their income in one day. However, even though mothers are aware that cigarette smoke is harmful to children's health, mothers cannot do anything to forbid their husbands from smoking in their homes or near their children. 
If viewed from an economic point of view, the expenditure on cigarettes is quite large when compared to the income of fishermen reaching only IDR 50,000 to IDR 70,000 for one time fishing (return day). Moreover, with climatic conditions that are difficult to predict at this time so that when fishermen go to sea, they do not necessarily get the expected catch. While the costs to be spent on smoking reach around $20 \%-40 \%$ of the income in one day.

However, the opportunity to influence father's smoking behavior is still there because father's concern for the health of children / family shows a positive response found that the mother (wife) is a significant other for father. The role of the wife in encouraging the negative behavior change of the husband related to health is greater than the role of the husband in terms of wife's behavior change (Westmaas, Ferrence, \& Wild, 2002).

Awareness of mothers and fathers to maintain their family's health is quite high and health is a top priority. However, their lack of awareness and knowledge of the effects of cigarette smoke on health is one of the obstacles for mothers to be able to ban their husbands from smoking.

There is an opportunity in conducting this research. The opportunity that emerged was that some mothers did not want their husbands to smoke and wanted their husbands to stop smoking and their family's health had also increased. The low level of education of mothers is also a challenge in this study. The "science" language contained in the training has to be reduced as much as possible so that it can be easily understood by the trainees. Likewise with the setting of activities should be adapted to the field conditions. In order for the activities to run well and the benefits can be felt by the subject in the future, the program should try to follow the patterns and rhythms of activities and abilities possessed by the community.

Based on the results of the study, it can be seen that the social support of the wife towards changes in husband's behavior towards positive change is determined by interpersonal sensitivity, empathy, and the level of expressiveness of the women. Women also prefer to use their children's health as an excuse to influence their husband's behavior. This is related to the role of women as gatekeepers of the health of families and care taker for their children. One way to provide social support to their partners in terms of changes in smoking behavior is through verbal communication and non-verbal communication as a form of emotional social support.

The social control function of the wife towards her husband in terms of changing the behavior from smoking near a child to smoking far from the child can be increased by providing the ability to be more assertive to prohibit the husband from smoking near the child. Under these conditions children and other family members will not become passive smokers. The intervention in the form of assertive communication is considered important in order for the father not to feel "offended" when his smoking habits are reprimanded by family members. Protecting children from cigarette smoke produced by their parents is the key to promoting children's health and can reduce sudden death syndrome in family members especially in children (sudden infant death syndrome - SIDS).

\section{CONCLUSIONS AND RECOMMENDATIONS}

Giving assertive communication skills to mothers has not led to an increase in father's smoking intentions outside the home. This is caused by several factors, namely the training material that needs to be adjusted in accordance to the subject's education level, and the lack of alternatives in the dynamics of the life of the fishing community. Efforts to increase father's smoking intentions outside the home can be done through further interventions using emotional-based training methods carried out periodically as well as supports from the health workers to monitor the community's behavior to improve the health status in their area. Other possibilities is also to advocate the local governments to issue smoking bans inside the house. 


\section{REFEREN C E S}

Astutie, Y. P., Hartati, S., \& Widiati, N. I. (2008). The Role and Potential of Coastal Women in Fulfilling Household Economic Needs in Tegal City.

Berger, C. R. (2005). Interpersonal Communication: Theoritical Perspective, Future Prospects . Journal of Communication, 415-447.

Blackburn, C., Bonas, S., Spencer, N., Dolan, A., Coe, C., \& Moy, R. (2005). Smoking Behaviour Change Among Fathers of New Infants. Social Science \& Medicine, 517-526.

Block, S., \& Webb, P. (2009). Up In Smoke: Tobacco Use, Expenditure on Food, and Child Malnutrition in Developing Countries.

Blokland, E. A., Engels, R. C., Hale III, W. W., \& Willemsen, M. C. (2004). Lifetime Parental Smoking History and Cessation and Early Adolescent Smoking Behavior. Science Direct, 359-368.

Carlson, L. E., Goodey, E., Bennet, M. H., Taenzer, P., \& Koopmans, J. (2002). The Addition of Social Support to a Community - Based Large - Group Behavioral Smoking cessation Intervention: Improved Cessation Rates and Gender Differences. Addictive Behaviors, 547-559.

Dalton, J. H., Elias, M. J., \& Wandersman, A. (2001). Community Psychology, Linking Individual and Communities. California: Wadsworth Thomson learning.

Global Youth Tobacco Survey (GYTS) Indonesia. (2006). Jakarta: Global Youth Tobacco Survey (GYTS) Indonesia.

Goldsmith, D. J. (2004). Communicating Social Support. New York: Cambridge University Press.

Kementrian Kesehatan Republik Indonesia. (n.d.). Home. Retrieved from Depkes Website: http: //www.depkes.go.id /indekx.php /berita /press-release /1090- time-protect-woman-fromdanger-cigarette.html

Lakey, B., \& Cohen, S. (2000). Social Suport Theory and Measurement. In S. Cohen, L. G. Underwood, \& B.H. Gottlieb, Social Support Measurement and Interventions: A Guide for Health and Social Scientist (pp. 29-52). New York: Oxford.

Lichtenstein, E., Andrews, J. A., Barckley, M., Akers, L., \& Severson, H. H. (2002). Women Helping Chewers: Partner Support and Smokeless Tobacco Cessation. American Psychological Association, 273-278.

Romano, P. S., Bloom, J., \& Syme, S. L. (1991). Smoking, Social Support, and Hassles in an Urban AfricanAmerican Comunnity. American Journal of Public Health, 1415-1422.

Samet, J. M., Lewit, E. M., \& Warner, K. E. (1994). Involuntary Smoking and Children's Health. The Future of Children - Critical Health Issues for Children and Youth, 94-114.

Sarason, I. G., Levine, H. M., Basham, R. B., \& Sarason, B. R. (1983). Assesing Social Support: The Social Support Questionnaire. Journal of Personality and Social; Psychology, 127-139.

Surachman, E. (2011). Problems of Child Education in Fishermen Families: Case Study of Marga Mulya Village, Mauk District, Tangerang, Community, 49-56.

Westmaas, J. L., Ferrence, R., \& Wild, T. C. (2002). Effects of Gender in Social Control of Smoking Cessation. American Psychological Association, 368 - 376. 